\title{
Ethnoknowledge of uçá-crab collectors, Ucides cordatus (Linnaeus, 1763) (Crustacea: Decapoda), in the Várzea do Una Mangroves (São José da Coroa Grande, Pernambuco, Brazil)
}

\section{André dos Santos', Victor Hugo Moreira de Lima², Wed'lla Thaís Barbosa da Silva ${ }^{3}$, Emanuelle Angélica Silva $^{3}$ and Manoel Lucas Bezerra de Lima ${ }^{4}$}

${ }^{1}$ Universidade de Pernambuco. Campus Mata Sul. Avenida José Américo de Miranda, S/N. Santa Rosa. Palmares-PE. Brazil. (CEP 55540-000).

${ }^{2}$ Laboratório Central de Saúde Pública Dr. Milton Bezerra Sobral. Secretaria Estadual de Saúde. Rua João Fernandes Vieira, S/N. Soledade. Recife-PE. Brazil. (CEP 50050-215).

${ }^{3}$ Faculdade de Formação de Professores da Mata Sul. Rodovia BR-101. Campus Universitário. Palmares-PE, Brazil. (CEP 55540-000).

${ }^{4}$ Universidade Federal de Pernambuco - UFPE/CAV. Rua Alto do Reservatório, S/N. Bela Vista. Vitória de Santo Antão-PE. Brazil. (CEP 55608-680).

\begin{abstract}
The catch of crab within the estuarine complexes is the main economic source of riparian communities throughout Northeastern Brazil. This study aimed to investigate the ethnoknowledge of uçá-crab collectors in the District of Várzea do Una, in the Municipality of São José da Coroa Grande (Pernambuco State, Brazil), as well as to infer on their perception regarding the activity of catching the uçá-crab Ucides cordatus (Linnaeus, 1763) (Crustacea: Decapoda), and regarding the mangrove. For the evaluation of ethnobiological and socio-economic issues relating to the crab collectors, a structured questionnaire was applied. Regarding the socio-economic profile of the collectors, they are professionals with a poor quality of life, with no prospect of progression, living in permanent preservation areas, and extracting from them the resources to survive. It was demonstrated that the studied community of uçá-crab collectors strongly interacts with the mangrove, and the empirical knowledge, in several situations, perfectly correlated with the data available in the scientific literature. Thus, it becomes evident that the knowledge of the crab collectors can contribute to scientific studies and should be considered in the development of actions aiming at the local management and preservation of this fishery resources.
\end{abstract}

Keywords: Mangrove; Preservation; Collectors.
Received May 12, 2017

Accepted June 27, 2017

Released June 30, 2017
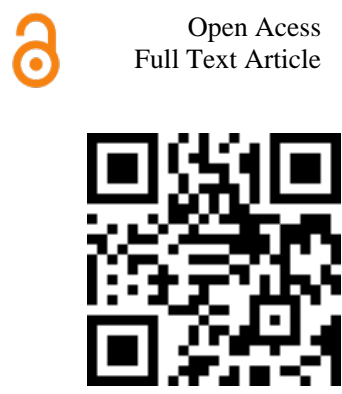

ORCID

(1) 0000-0002-9700-9815 André dos Santos

(1) 0000-0003-2601-768X Victor Hugo Moreira de Lima

(1) 0000-0002-1922-3250 Wed'lla Thaís Barbosa da Silva

(D) 0000-0002-5873-6833 Emanuelle Angélica Silva 


\section{Introduction}

The Brazilian mangroves cover approximately $25,000 \mathrm{~km}^{2}$, including areas from the extreme north of Amapá State (latitude $4^{\circ} 30^{\prime} \mathrm{N}$ ) to the extreme south of Santa Catarina State (latitude $28^{\circ} 53^{\prime} \mathrm{S}$ ). Currently, Brazil is the third country with the largest mangrove areas in the world (Giri et al., 2011), providing a wealth of resources for several coastal communities (Alves et al., 2005; Santos et al., 2016; Santos et al., 2017).

The use of mangrove resources arose in remote times, dating from 7,000 to 10,000 years ago, evidencing the use of mangrove fauna, such as crabs, mussels, oysters, and fish, by prehistoric nomadic tribes, and can be proved by the existence of sambaquis (kitchen midden or shell heap) distributed along the coast (Alves and Nishida, 2003). Therefore, the relevance of the mangroves transcends the ecological scope, with economic, social and cultural importance.

Crabs collection is the main economic activity of the traditional communities from mangrove areas. Among the species commercialized in Brazil, the most prominent are Cardisoma guanhumi (Latreille, 1828), Goniopsis cruentata (Latreille, 1802), Callinectes spp, and Ucides cordatus (Linnaeus, 1763), popularly known as uçá-crab. The latter one is the most relevant species for the economy of the riparian populations (Capistrano and Lopes, 2012; Alves and Nishida, 2003).

In general, the capture of uçá-crab is carried out individually, manually or with instruments, made by the collector to facilitate the collection, such as nets, cutters, among others. The capture can also be carried out without boats or any type of infrastructure, predominately performed by groups of people with no permanent employment, who use the resource availability to obtain income.

The knowledge of the collectors about the ecosystems in which they are inserted constitutes a valuable inheritance that modernity cannot do without. Mangrove is important in the subsistence economy of several coastal communities, in which the assessment of ecosystem potential can serve as a basis for establishing the sustainability of extractive activities since mangroves have a high biological productivity (Morbeg and Ronnback, 2003).

This study aimed to investigate the ethnobiological aspects involved in the capture, commercialization, and interaction of the uçá-crab collectors with the environment, to better understanding the environmental perception by the collectors and their awareness of environmental issues. The empirical knowledge of the crab collectors is fundamental for the implementation of social programs aimed at improving the quality of life of these workers, as well as for the development of programs for the management and conservation of natural resources, especially the uçá-crab.

\section{Method}

The present study was conducted in the Estuary of the Una River, located in the Várzea do Una Village $\left(08^{\circ} 50^{\prime} \mathrm{S}\right.$, $35^{\circ} 09^{\prime}$ W), in the Municipality of São José da Coroa Grande, South coast of Pernambuco State, Brazil (Figure 1). The study area is in the Environmental Protection Area of the Coral Coast, bordering Alagoas State. 


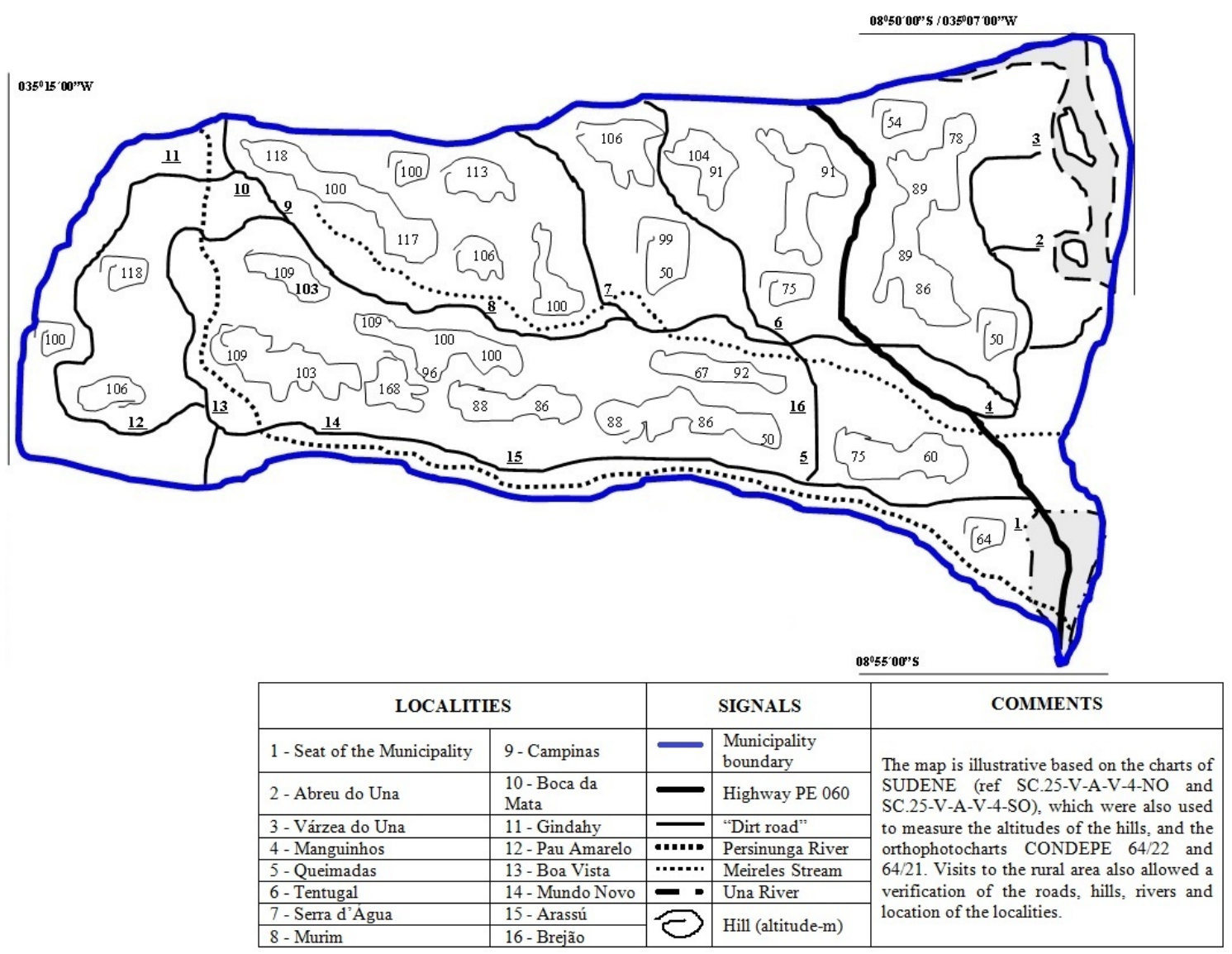

Figure 1. Location of the Várzea do Una Village, in the Municipality of São José da Coroa Grande. Source: Una Museum.

The research was carried out in October 2016, during the crab collectors' activity and in informal meetings near their homes. The data were obtained through open and semi-structured interviews. The interviews followed ethnoscientific precepts with a balanced emicist-ethicist approach (Sturtevant, 1964). Collectors $(\mathrm{N}=20)$ of both genders were interviewed. They were contacted using the snowball technique (Goodman, 1961). The interviews took place in different contexts and had an average duration of $30 \mathrm{~min}$ and addressed socioenvironmental and ethnobiological issues relating to the uçá-crab collectors. Direct observations were also made, accompanying the informants in their routine activities.

The ethnographic data were analyzed by the frequency of occurrence. Photographic records were made whenever possible, and their publication was allowed by the respondent, who were asked to sign a consent form.

\section{Results and discussion}

The anthropic activities in the study area are related to the disordered occupation and to the inadequate use of the soil. Deforestation and landfills are carried out by the population with the purpose of building houses and disposing of domestic effluents, and solid waste is directly disposed of in the mangrove.

The age of the collectors ranged from 18 to 65 years, with an average of 45 years, characterizing a contingent that complements the family income through the collection of crab-uçá. Regarding marital status, about $50 \%$ were unmarried, $40 \%$ married, $5 \%$ concubinage, and $5 \%$ 
divorced. Most of them have completed primary and secondary education (60\%), whereas the others $(40 \%)$ have no level of education. This result characterizes the crab population of this community as poorly qualified, as already observed in other areas of the Brazilian coast (Alves and Nishida, 2003).

Working time as a crab collector ranged from 5 to 30 years, with $30 \%$ of respondents depending on this resource as the only source of income, earning an average of 1 minimum ( $\mathrm{R} \$ 937.00)$ wage to survival. The low income of these workers may be related to low schooling or traditional way of life, based on subsistence production.

During crab collection, the animals are captured by a mousetrap, machete and or "braceamento" (using the arm) (20\%), although $80 \%$ use the "redinha" (little-net technique) (Figure 2). The use of little-net by the collectors to capture the crab has caused the decrease of the species (Table 1). These techniques were reported by other authors who discussed the ethnobiological and socio-economic issues relating to the crab collectors (Albuquerque and Albuquerque, 2005).

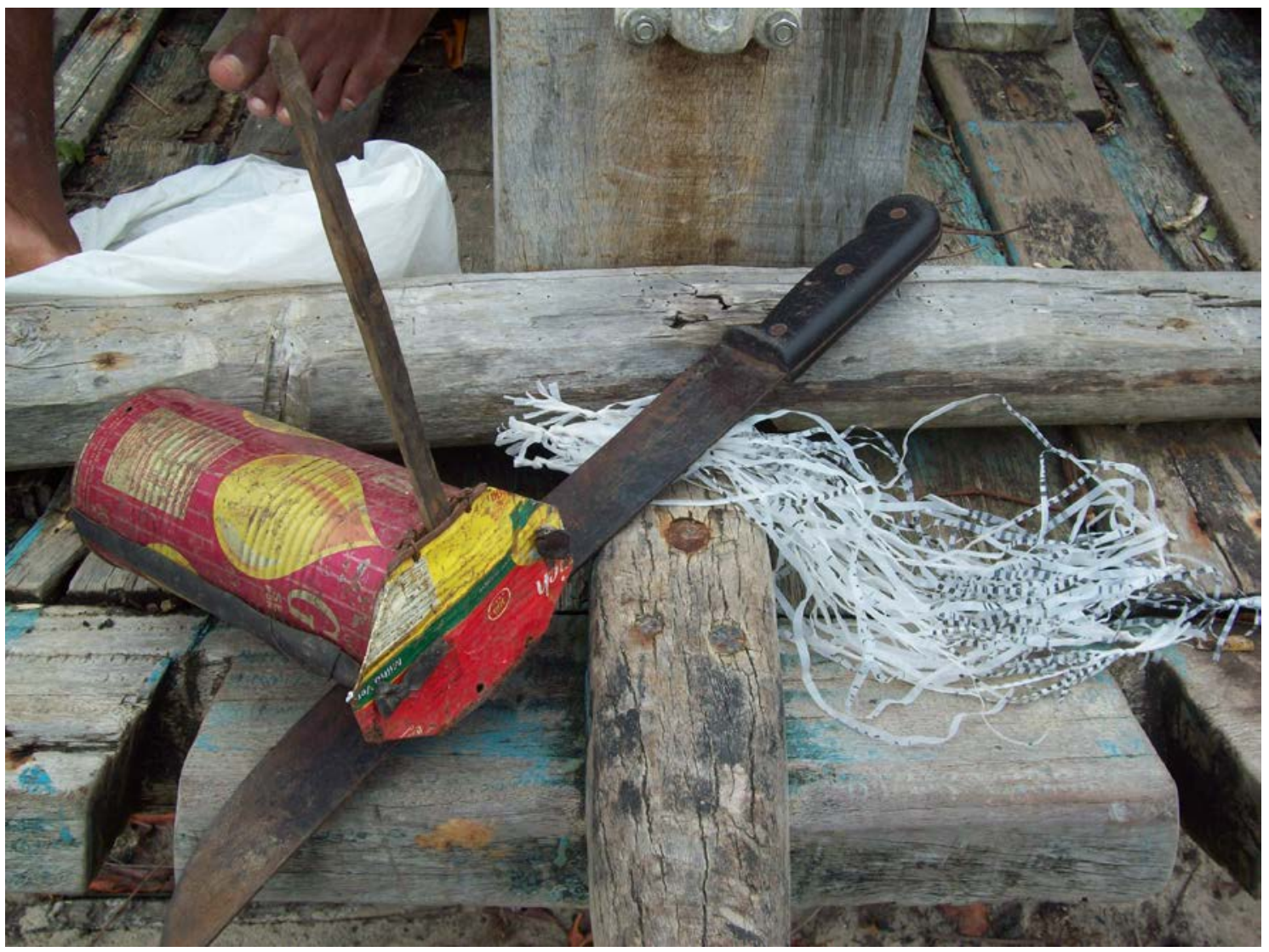

Figure 2. Tools used by the collectors during the uçá-crab capture.

Crab captures are performed in 3 or 4 days per week, with an average extraction of 20 ropes/day (each rope contains 10 crabs). The collectors move in the mangrove by walking. Most of them are men (85\%), children and adolescents also participate in this activity. The low participation of women is justified by their dedication to the care of the house and the children. 
Table 1. Description of the main tools and techniques used in the artisanal capture of uçá-crab in the Várzea do Una mangroves.

\begin{tabular}{l|l}
\hline $\begin{array}{l}\text { Crab capture technique } \\
\text { and tools }\end{array}$ & \multicolumn{1}{c}{ Description } \\
\hline Redinha (Little-net) & $\begin{array}{l}\text { Little-net is a tangle of thread removed from polypropylene bag, which is } \\
\text { placed at the entrance of the crab’s burrow to trap the animal when it comes } \\
\text { out to breathe and eat. This tool can catch from sixty to seventy crabs. This } \\
\text { technique requires little physical effort, but it has the disadvantage of } \\
\text { catching crabs of any age and ovigerous females. }\end{array}$ \\
\hline Mousetrap & $\begin{array}{l}\text { The mousetrap used to capture crabs is a kind of trapdoor made with oil can } \\
\text { and wood. Few collectors use the mousetrap to capture the uçá-crab, most of } \\
\text { them use this trap to capture crabs of other species. This technique consists } \\
\text { of placing a vegetable bait (coconut or leaves) into the mousetrap to attract } \\
\text { the animal. The main advantage of this technique is the low cost to make } \\
\text { this tool since it is made of oil can and wood only. }\end{array}$ \\
\hline Machete & $\begin{array}{l}\text { The machete is a tool used for drilling and cutting during. It serves to cut } \\
\text { aerial roots of the mangrove to facilitate the capture and to make possible } \\
\text { the use of some techniques used by the collectors. }\end{array}$ \\
\hline Braceamento & $\begin{array}{l}\text { It is the traditional method of capture, allowed by IBAMA legislation. It } \\
\text { involves a direct contact of the collector with the substrate of the mangrove, } \\
\text { consisting of inserting the arm inside the burrow or gallery to extract the } \\
\text { crab. This technique requires a lot of physical effort and causes injuries to } \\
\text { the hands and arms. }\end{array}$ \\
\hline
\end{tabular}

Most collectors (80\%) are not associated with cooperatives, and they sell the crabs at free fairs, at the beach, in bars and restaurants. This fact was also observed by Maneschy (1993) among crab collectors in Pará State, suggesting that the demobilization of this category translates the fact that they incorporate a devalued and stereotyped image of their work. The crabs are sold alive and tied to ropes, each one containing 10 animals, which are kept in covered barrels, cans or tanks with water until they are sold. The price of each crab rope ranged from $\mathrm{R} \$ 8.00$ (eight reals) to $\mathrm{R} \$ 10.00$ (ten reals).

From data analysis, it was noticed that $80 \%$ of the collectors know about the legislation that prohibits the capture of the Ucides cordatus crab during its reproduction period ("andada") and when there are ovigerous females (Brasil, 2014). However, even knowing the environmental laws, these crustaceans are caught indiscriminately, and the collectors are not afraid of punishment.

For the majority of the respondents (90\%) know the prohibition period of capture and agree with the uçá-crab closed season (MPA/MMA No. 1 of January 13, 2011). These findings are similar to those of Oliveira and Rangel (2016). A total of $80 \%$ of the collectors were aware of the uçá-crab closed season through the Brazilian Institute of Environment and Renewable Natural Resources (IBAMA) and $20 \%$ through acquaintances or relatives. However, all of them would change the prohibition period, even knowing that, in this period, there are more ovigerous females in the muddy mangroves. These data differ from those found by Fiscarelli and Pinheiro (2002), who verified that a little more than half of the respondents would not change the date of the uçá-crab closed season.

The significant reduction in the population of uçá-crab in the mangrove of the Várzea do Una Village is mainly due to the behavior of the collectors and the pollution caused by the riparian community. During the reproduction period (Brazil, 2014), the collectors capture a higher number of uçá-crab, even though they know the law that preserves this period, interfering with the natural reproduction of this species. During 
informal conversations, the collectors admitted they were responsible for the mangrove conditions in the Várzea do Una Village, pointing out that "from where it is extracted with no supply, only remains bankrupt”.

\section{Conclusions}

There is a significant impact on the reduction of fishing resources in the Várzea do Una village, due to the disorderly capture of the Ucides cordatus crab. Part of these environmental impacts is caused by the community since in much of the mangrove area the species is endangered. According to the collectors, the number of crabs captured in comparison to a few years ago has significantly reduced. However, awareness regarding the moderate capture and capture methods that do not affect the permanence of life in the mangrove should be considered by the collectors, as well as the use of alternative means of working to improve the living conditions of the riverine population. Due to their significant interaction with the mangrove, the collectors have an empirical knowledge, which in some cases correlate with the one found in the scientific literature. In this sense, measures aimed at the management and preservation of this species are needed, in partnerships with the community and the public power.

\section{Conflict of interest statement}

Authors declare that they have no conflict of interests.

\section{References}

Albuquerque, C. A; Albuquerque, U. P. Local perceptions towards biological conservation in the community of Vila Velha, Pernambuco, Brazil. Interciencia, v. 30, no. 8, p. 460-465. 2005. Available from: http://www.scielo.org.ve/ scielo.php?script=sci_arttext\&pid=S0378-

18442005000800006. Accessed on: Apr. 23, 2017.
Alves, R. R. N.; Nishida, A. K. Aspectos socioeconômicos e percepção ambiental dos catadores de caranguejo-uçá, Ucides cordatus cordatus (Linnaeus, 1763) (Decapoda, Brachyura) do Estuário do Rio Mamanguape, Nordeste do Brasil. Interciência, v. 28, No. 1, p. 36-43, 2003.

Alves, R. R. N.; Nishida, A. K.; Hernández, M. I. M. Environmental perception of gatherers of the crab 'caranguejo-uçá' (Ucides cordatus, Decapoda, Brachyura) affecting their collection attitudes. Journal of Ethnobiology and Ethnomedicine, 1:10, 2005. https://dx.doi.org/ 10.1186/1746-4269-1-10

Brasil. Instrução Normativa Interministerial $\mathbf{n}^{\circ}$ 9, de 30 de dezembro de 2014. Regulamenta, no período da "andada”, a pesca do caranguejo-uçá nos Estados do Pará, Maranhão, Piauí, Ceará, Rio Grande do Norte, Paraíba, Pernambuco, Alagoas, Sergipe e Bahia, nos anos de 2015 e 2016. Available from: $<$ http://pesquisa.in.gov.br/imprensa/jsp/visualiza /index.jsp?data=02/01/2015\&jornal=1\&pagina= 81\&totalArquivos $=128>$. Accessed on: Apr. 23, 2017.

Capistrano, J. F.; Lopes, P. F. M. Crab gatherers perceive concrete changes in the life history traits of Ucides cordatus (Linnaeus, 1763), but overestimate their past and current catches. Ethnobio. Conserv., 1:7, 2012. https://dx.doi.org/10.15451/ec2012-8-1.7-1-21

Fiscarelli, A. G; Pinheiro, M. A. A. Perfil sócioeconômico e conhecimento etnobiológico do catador de caranguejo-uçá, Ucides Cordatus (Linnaeus, 1763), nos Manguezais de Iguape ( $24^{\circ} 41^{\prime}$ S), SP, Brasil. Actual Biol., v. 24, No. 77, p. 129-142, 2002. Available from: <http://www.crusta.com.br/biblio/01.Artigos/24 -Fiscarelli.e.Pinheiro.(2002).-.Perfil.catadores. de.Ucides.pdf>. Accessed on: Apr. 23, 2017.

Giri, C.; Ochieng, E.; Tieszen, L. L.; Zhu, Z.; Singh, A.; Loveland, T.; Masek, J.; Duke, N. Status and distribution of mangrove forests of the world using earth observation satellite data. Global Ecology and Biogeography, v. 20, No. 1, p. 154-159, 2011. https://dx.doi.org/ 10.1111/j.1466-8238.2010.00584.x

Goodman, L. Snowball sampling. The Annals of Mathematical Statistics, v. 32, No. 1, p. 148-170, 1961. Available from: <https://www.jstor.org/stable/pdf/2237615.pdf>. Accessed on: Apr. 23, 2017. 
Maneschy, M. C. Pescadores nos manguezais: estratégias técnicas e relações sociais de produção na captura de caranguejo. In: Furtado, L.; Leitão, W.; Melo, A. F. (Eds.). Povos das águas: realidade e perspectivas na Amazônia. Belém: Museu Paraense Emílio Goeldi, 1993. p. 19-62.

Moberg, F.; Ronnback, P. Ecosystem services of the tropical seascape: interactions, substitutions and restoration. Ocean Coast. Manag., v. 46, p. 27-46, 2003.

Oliveira, E. M. S.; Rangel, L. F. A. Ethnobiological knowledge of crab collectors Ucides cordatus (Linnaeus, 1763) (Crustacea, Decapoda) in the Gargaú District, São Francisco do Itabapoana/RJ. Campos dos Goytacazes: Fluminense Federal Institute, 2016. (Monograph in Environmental Education). Available from: <http://bd.centro.iff.edu.br/ bitstream/123456789/941/1/Artigo EA_Eliana_ Fellipe.pdf>. Accessed on: Apr. 23, 2017.

Santos, L. C. M.; Gasalla, M. A.; DahdouhGuebas, F.; Bitencourt, M. D. Socio-ecological assessment for environmental planning in coastal fishery areas: a case study in Brazilian mangroves. Ocean \& Coastal Management, v. 138, p. 60-69, 2017. https://dx.doi.org/ 10.1016/j.ocecoaman.2017.01.009

Santos, L. C. M.; Pinheiro, M. A. A.; DahdouhGuebas, F.; Bitencourt, M. D. Population status and fishery potential of the mangrove crab, Ucides cordatus (Linnaeus, 1763) in NorthEastern Brazil. Journal of the Marine Biological Association of the United Kingdom, 2016. https://dx.doi.org/10.1017/ S0025315416001259

Sturtevant, W. C. Studies in ethnoscience. American Anthropologist, New Series, v. 66, No. 3, Pt. 2, p. 99-131, 1964. https://dx.doi.org/ 10.1525/aa.1964.66.3.02a00850

License information: This is an open-access article distributed under the terms of the Creative Commons Attribution License, which permits unrestricted use, distribution, and reproduction in any medium, provided the original work is properly cited. 